\title{
The Evolution of a B.S. Internet/Web Program at Purdue University Calumet
}

\author{
Charles R. Winer and John Maniotes \\ Purdue University Calumet, Hammond, IN 46323 USA
}

winer@calumet.purdue.edu maniotes@calumet.purdue.edu

\begin{abstract}
The growth of the Internet and the impact of the Community College system in Indiana have had a profound impact on the traditional two and four year programs in Computer Information Systems (CIS). Purdue University Calumet has recognized this impact and has revised and implemented an innovative Internet/Web B.S. program and related courses to support it. The B.S. program was developed and refined with input from the University's local business/industry advisory committee. This paper presents the new four year Internet/Web B.S. program, which gives students a strong foundation in basic concepts and a high degree of employability.
\end{abstract}

Keywords: IT Curriculum, Internet/Web Programs, E-Commerce, E-Business

\section{Introduction}

Purdue University Calumet offers extensive instruction and programs in the area of Information Systems (IS), ranging from the certificate to the Master of Science degree. Purdue University Calumet has offered IS programs since 1963. These programs have been described by (Maniotes 1973), (Mick 1999), and by (Winer \& Maniotes 2001).

Currently, the Information Systems \& Computer Programming department (ISCP) of Purdue University Calumet offers a Bachelor of Science degree in each of the following options:

1. Systems Analysis and Database Design

2. Software Development

3. Networking

4. Software Engineering

5. Information Systems Technology Supervision

6. Internet/Web

This paper describes the evolution of a new undergraduate four year Internet/Web program. In addition, specific courses as they relate to the program are described, as well as the challenges faced by the program.

Material published as part of these proceedings, either on-line or in print, is copyrighted by Informing Science. Permission to make digital or paper copy of part or all of these works for personal or classroom use is granted without fee provided that the copies are not made or distributed for profit or commercial advantage AND that copies 1) bear this notice in full and 2) give the full citation on the first page. It is permissible to abstract these works so long as credit is given. To copy in all other cases or to republish or to post on a server or to redistribute to lists requires specific permission from the publisher at Publisher@InformingScience.org

\section{Background and State Mandate}

Until 2001, the State of Indiana was one of the few states in the United States that did not have a formal community college system. After graduating from high school, a student could attend a state supported university, college, or vocational education institution. 
Prior to 2001, many of the state's universities and colleges offered associate degrees, in addition to baccalaureate and graduate level degrees. At Purdue University Calumet, students could earn an associate degree as well as a baccalaureate degree in any of the six (6) options previously identified.

Under these conditions, the baccalaureate program was a two-year "add-on" curriculum, open to qualified associate degree graduates of a particular program. This was also known as the $2+2$ degree program.

In 2001, the state mandated the establishment of a community college system, which would offer career development certificates and 2-year programs, leading to associate degrees. Graduates of these 2-year degrees then had the opportunity to transfer their credits and continue pursuing their 4-year program at Purdue University Calumet. This mandate also allows Purdue University Calumet to expand and enhance their baccalaureate and graduate degree programs.

The Information Systems \& Computer Programming department has changed and enhanced its Internet/Web program from a $2+2$ program to a 4 -year baccalaureate degree program. In order to meet Purdue University Calumet's goal of becoming primarily a traditional 4-year degree granting institution, the 2year associate degree Internet/Web option has been removed from this program. The concentration of general education course has been increased to $40 \%$ of the overall curriculum.

These changes will enable community college students who have completed an associate degree to transfer their specific courses into the enhanced 4-year Internet/Web degree program at Purdue University Calumet.

\section{Goals of the Internet/Web Program}

The goals of this program are to prepare students to become proficient in:

1) System development methodologies to analyze the needs for corporate Web sites.

2) Development of corporate Web sites, using a wide variety of languages and tools, including but not limited to $\mathrm{C}++$, Visual Basic, JAVA, HTML, scripting languages, and FrontPage.

3) Implementation and maintenance of corporate Web sites.

4) Evaluation and recommendation of new technologies for corporate Web sites.

5) Selection and utilization of appropriate Web server technologies.

6) Installation, maintenance, and management of Web servers.

7) Evaluation and recommendation of Internet solutions to workgroup, enterprise, and interenterprise problems and opportunities.

8) Intranet and extranet concepts and technologies.

9) Evaluation and recommendation of E-Commerce solutions.

10) Installation of effective security measures at corporate Web sites.

\section{The Four Year Internet/Web B.S. Program}

Currently, the Internet/Web program is designed to produce graduates in the occupation group, whose job titles may be: Web Programmer, Web Developer, and Web Administrator.

The curriculum of the Internet/Web program is divided into four areas:

1) IS, networks, and computer basic concepts

2) Programming languages used to develop Internet/Web applications

3) Organization of business and business applications. 
4) Supporting sciences and electives

During the first year of the program, as indicated in Appendix A, the students acquire an introduction to Computer Systems Architecture, C++ Programming, Systems Analysis and Design, and Networks. In addition, they study such academic courses as English composition, Communication (speech) fundamentals, and Mathematics. In the second year, the students concentrate heavily in web development and programming applications using $\mathrm{C}++$, Visual Basic, JAVA, and HTML. During this second year, students learn about E-commerce applications, operating systems, and database techniques. In addition, the students continue their related course study in areas such as: economics, the humanities and social sciences.

An important point to keep in mind is that the first two-years emphasize the practical, rather than the theoretical aspects of the Internet/Web. Strong emphasis is place on "real-life" laboratory exercises, which are intended to reinforce the student's knowledge of IS techniques by requiring the student to apply them to a broad spectrum of Internet/Web applications.

As indicated in Appendix A, the third and fourth years of the program emphasize the practical aspects of such areas as multimedia for Web designers, object oriented analysis design, database programming and administration, advanced JAVA programming and Web development, Internet/Web security, Web server management, and a senior system development project. The inclusion of many elective courses enables the student to pursue areas of special interest. Listed below are some of the pertinent Internet/Web courses, with a brief description of each course.

CIS 140 Introduction to Networks (Class 3, Credit 3)

This course is an introduction to computer networks. How networks are used in business and industry environments is explained. The various types of communication equipment and cables used in networks is also explained. The difference between local area and wide area networks is introduced, as well as exploring analog and digital transmission, and the concepts involved in transmitting data. Network design and the implementation of those designs are an integral part of the course. Students use a graphical software package to create network diagrams.

\section{CIS 166 Introduction to C++ I (Class 2, Lab 2, Credit 3}

This course is an introduction to programming using $\mathrm{C}++$. Emphasis in this course is on structured programming and top-down design. Topics include identifiers, data types, arithmetic and logical operators, if, if/else, while, for, switch, do/while, functions, arrays, pointers, strings, struct and introduction to classes. (Raoufi \& Maniotes 2000).

\section{CIS 217 Object Oriented Programming (Class 2, Lab 2, Credit 3)}

The object oriented application development method has replaced structured development techniques as the development method of choice. This course is a continuation of object-oriented program development as it applies to Web development. An overview of object-oriented analysis and design techniques and terminology is presented. Object-oriented programming techniques are implemented using a visual programming environment, such as Visual Basic.

\section{CIS 241 Web Development I (Class 2, Lab 2, Credit 3)}

This course is an in depth study on the Internet and World Wide Web. Topics include intra-, inter, and extranet concepts, security issues, design criteria and other Web aspects. Focus is on teaching skills necessary to design and develop applications for use on the Internet. Students learn how to write HTML, VBScript, and JavaScript code, how to use Microsoft FrontPage, and other tools to create Web pages. In addition, students learn how to use image maps, forms and scripts, frames, animated GIF files, tables, and style sheets. Students complete a semester long project, working as a member of a team.

CIS 242 E-Commerce Architecture (Class 3, Credit 3) 
This course is an introduction to client/server and Web-based architecture. Topics include the history and evolution of client/server systems, standards, client/server processing models, the role of the client and of the server, middleware, multi-tiered architectures, methods of data distribution, designing a client/server system, distributed RDBMS, transaction processing and E-commerce. New developments, trends and uses for E-commerce are discussed.

\section{CIS 263 JAVA Programming (Class 2, Lab 2, Credit 3)}

This course is an introduction to the JAVA programming language. The language is used for creating object-oriented software, particularly for applications to be used on the Internet. Students study the structure and style of JAVA and are required to submit extensive programming laboratory exercises.

CIS 266 Introduction to $\mathrm{C}++$ II (Class 2, Lab 2, Credit 3)

This course is a continuation of the CIS 166 Introduction C++ I. It provides advanced skills using the $\mathrm{C}++$ programming language. Students should be prepared for an entry-level programming position using $\mathrm{C}++$. Emphasis in this course is on object-oriented paradigm, using $\mathrm{C}++$. Topics include definition of classes, data abstraction, friend member functions, this pointer, static class member, operator overloading, inheritance, virtual function and polymorphism, template, exception handling, elementary data structures, reusability, and introduction to standard template library. (Raoufi \& Maniotes 2000).

\section{CIS 341 Web Development II (Class 2, Lab 2, Credit 3)}

This course is a continuation of the CIS 241 Web Development I. Advanced features and techniques for developing sophisticated Web content, as well as new trends in Web development are covered. Other topics include using advanced multimedia and database and application integration.

\section{CIS 342 Multimedia for Web Designers (Class 2, Lab 2, Credit 3)}

The developments on the World Wide Web have created demand for skills in developing multimedia suitable for use in complex Web sites. This course in an introduction to the creation and use of graphics, animation, video and audio on the Web. Students will design, create and deploy several instances of graphics, video and audio on a series of Web pages. Topics include graphics, video, and audio file formats, creating multimedia content, formatting images on Web pages, animation and video, and the use of graphics for purposes such as buttons, dividers, and image maps.

CIS 356 Topics in Database Programming (Class 2, Lab 2, Credit 3)

The computing industry has moved from storing data in individual files to using some form of database system. Current students must have database programming experience to be productive in this modern environment. This course is an introduction to accessing a relational database using a programming language such as $\mathrm{C}++$ or JAVA. The focus is on one language during the semester. Topics include defining and controlling transactions, sequential access techniques, use of primary and secondary keys, cursors, report generation, updating techniques, and dynamic SQL.

CIS 363 Advanced JAVA Programming (Class 2, Lab 2, Credit 3)

This course is a continuation of CIS 263 JAVA programming. Advanced features and techniques for developing sophisticated JAVA programs, as well as new trends in JAVA development are covered. Topics include multi-threading, client/server, database access and exception handling.

\section{CIS 426 System Development Project (Class 3, Credit 3)}

As a student approaches the completion of their degree requirements, they should be able to use the skills and concepts they acquired to design, create and deploy a non-trivial computer system or application. This course represents a capstone course that integrates the knowledge, skills and abilities gained through the computer-related courses in the curriculum within a comprehensive system development project. 


\section{CIS 441 Web Server Management (Class 2, Lab 2,Credit 3)}

The developments on the World Wide Web have created demand for skills in installing and maintaining Web sites and Web server software. This course is a study of the implementation, configuration and maintenance of Web server software. Students will install and configure a Web server. Topics include server layout and design considerations, CGI, and back-end program management, data collection and management, backup and recovery procedures, security and secure transactions and logging and auditing.

\section{CIS 442 Internet/Web Security (Class 3, Credit 3)}

Recent events documented in the media reflect the importance of reliable and effective security measures for securing computing facilities and data. This course is a study of existing methods and techniques for securing various components of computerized systems. Topics include types of attacks, monitoring and detection techniques, encryption methods, data security, authentication techniques and current trends in security.

\section{CIS 457 Database Administration (Class 2, Lab 2, Credit 3)}

This course covers database administration tasks and techniques. Students will install and implement two relational database management systems. Topics include RDBMS architecture, installation, configuration, creating databases, migrating data, database object management, user account management, tuning and backup and recovery.

\section{Business/Industry Advisory Committee}

The Information System \& Computer Programming department's business/industry advisory committee has grown over the past few years to include individuals from up to twenty varied businesses and industries, such as: steel companies, metal fabricators, oil refineries, manufacturing companies, utilities, and local government officials. Many of these organizations have hired our graduates over the years. An average of fifteen representatives now attend the twice a year- advisory committee meetings. For the past four years, this committee met with the faculty and departmental staff every semester to guide the department in the development and enhancement of the Internet/Web program, courses, laboratory needs, etc. The committee and the members of the Information Systems \& Computer Programming department have had a professional relationship on fine tuning the program and discussing what works, what doesn't work, and more importantly why not.

\section{Challenges Faced by the Program}

Summarized below are some of the challenges faced by Internet/Web program. Although some of these challenges may be pertinent to Purdue University Calumet, others are general enough to apply to other institutions, which have similar academic programs.

\section{Staffing}

A problem that the Internet/Web staff faces is the constant updating required in their field, as compared to their colleagues in the humanities and liberal arts. It has been said that the half-life of one's Internet/Web knowledge obsoletes every two years, due to the many new developments that are occurring in the field. Recognizing this problem, the staff has been periodically infused with new Internet/Web knowledge through attendance and engagement at the following activities:

a) Seminars and courses sponsored by professional organizations and software vendors

b) Various consulting assignments in business and industry.

c) Summer Institutes 
Furthermore, the campus library's selection of Internet/Web oriented books and journals has been expanded so as to enable to the staff to remain abreast of the latest developments in this ever changing field. The department also subscribes to the latest industry weekly/monthly trade publications and professional magazines.

Another problem that has been experienced in recent years concerns the difficulty in hiring experienced instructors, who possess up-to-date knowledge about the Internet/Web and its associated applications. One of the problems contributing to this difficulty has been the low starting salaries and poor fringe benefits commonly found in the teaching profession.

The job description for a tenure track faculty position in the department prefers the candidate have an earned Ph.D. degree. However, an M.S. degree in CIS or other related field will be considered. Significant computer information systems, business/industry experience is required. Preference is given to applicants with teaching and business experience. Applicants should be able to teach courses in Web development and E-commerce. The ability to teach networking and operating systems is also a plus.

University administrators must be constantly made aware that Internet/Web staff members have unique problems and additional resources must be made available to compensate for these deficiencies. The demand for competent and experienced Internet/Web instructors is high and the supply has a long way to go to meet demand.

\section{Instructional Materials}

Currently, good textbooks, student workbooks/manuals, and visual aids exist for the introductory Internet/Web courses and for the programming courses, such as C++, Visual Basic, JAVA, HTML, and XML, which appear in the freshman and sophomore levels of the program. However, good textbooks, student work manuals, and visual aids for the Junior and Senior levels of the program are sparse. The courses which require good student oriented textbooks are: E-Commerce and E-Business architecture, Internet/Web Security, Web Server Management, Advance Web Development, and Multimedia for Web Designers.

The text material for these courses usually consists of reference manuals from software vendors, notes from the instructor, or handouts oriented for experienced professionals, rather than for students. More effort needs to be exerted by textbook publishers in producing good student-oriented textbooks for these courses.

\section{Funds and Tuition Increases}

Adequate funding is needed to purchase, rent, or lease modern workstations, PC's, laptops, peripheral equipment, multimedia devices, and Internet/Web software packages and tools is a problem faced by Purdue University Calumet.

A question often asked is: "Where will additional funds come from?" We don't think there will be any significant outlays of funds from federal and state government sources. However, there will be student tuition increases.

When the University's Board of Trustees approved the campus strategic plan in the Fall of 2001, it was determined that funding for the campus would come from a combination of sources, including a student tuition increase of $\$ 16$ per credit hour for new students. For Fall 2002, new per credit hours costs will be $\$ 125$ for resident undergraduates and $\$ 158$ for resident graduate students.

The strategic plan calls for a greater focus on student success, including retaining and graduating more entering students. To do that, the University plans to add more full-time faculty and provide them with greater support and professional development opportunities. 


\section{Partnering with Vendors}

At Purdue University Calumet, we have partnered with various software vendors to bring in some popular software packages in the program. For example, our faculty have partnered with private corporations to aid in getting accepted into the IBM Partners-In-Education (PIE) program. This program offers cost effective leasing arrangements to acquire iSeries hardware and free software to support E-commerce and Web enabled applications, using their DB2/Universal DBMS and their Websphere, E-commerce development tool. In addition, partnering with companies like Information Builders Inc. enables the University to utilize DBMS and WebFocus development tools at no cost to the University or its students.

Other software vendors, such as AutoDesk, Inc. enable the University to bring in their AutoCAD software package into the University for student and outside training needs. In addition, the following software products are also being used by multiple departments at the University: Matlab, Electronics Workbench, Borland $\mathrm{C}++$, Borland J Builder, Borland Delphi, MathCAD 2000 Pro, RSLogix 5, Emulate 5, OrCAD Layout and Capture, Microsoft Windows 2000 server, Novell Netware 5.1, MASM 6.11, Microsoft Visual Studio (C++, Basic, JAVA).

In addition, AutoCAD 2000i, Architectural Desktop, Mechanical Desktop, Land Development Desktop, Autodesk Inventor, 3D Studio VIZ; Parametric Technologies Pro/MECHANICA, Pro/ENGINEER, Pro/NC-MILL, Pro/FEM-POST, Pro/ASSEMBLY; Adobe Systems PhotoShop 6.0, Imageready 3.0; Macromedia Inc. Freehand 9.0, and Quark Inc. Quark Express software products are also utilized in the other academic departments of the University.

\section{Retention Rates of Internet/Web Majors}

The department has made a concentrated effort to retain Internet/Web majors from the freshman level to the sophomore year in all CIS courses. The department has provided for closed labs dedicated to the majors of students in the Information Systems \& Computer Programming department, instead of open labs, for most CIS courses. Whenever, possible, the department has assigned a full-time instructor, instead of part-time (guest lecturers) instructors, or graduate assistants and teaching assistants. In some cases, the department has also assigned a student assistant (teaching assistant) to help the instructor in the laboratory and to assist in grading the lab or homework exercises. Internet/Web courses that have a lecture/lab format are set to a maximum lecture size of 36 students and a lab size of 18 students.

We have found that retention rates generally are greater with the older, more mature students attending our evening classes, than the typical younger students, who attend the day classes. Retention rates from some of the introductory Internet/Web programming courses in C++ have averaged approximately $60 \%$ to $75 \%$ during the past three years (Raoufi \& Maniotes 2000).

\section{Conclusions}

Purdue University Calumet is at the cutting edge by spearheading a new enhanced B.S. Internet/Web program. For the Fall, 2001 semester, there were112 registered students who have declared their major as Internet/Web. For the Spring 2002 term, there were 110 registered students. Students are very excited and enthusiastic about these programs, which are the fastest growing programs at the University. These new programs are different than the traditional CIS, IS, MIS, and CS programs. The Internet/Web B.S. program will teach students about the technical, psychological, and social aspects of developing Web based applications and how these applications interact with the traditional legacy systems. Discussions on how to interact with legacy systems are held with examples of using Active Server Pages (ASP) as the means of accomplishing this function. 
Furthermore, students preparing to enter the work force should learn not only the basics, but also combine critical thinking and problem solving skills with knowledge of how the Internet/Web can be used more efficiently by business and industry.

The Internet is here to stay and it is available 24 hours a day. The Web is growing exponentially and so are its users. The demand for trained Web professionals currently exceeds the supply, even with the demise of many of the first generation dot coms. Hence the development of the four year Internet/Web program by Purdue University Calumet to provide graduates with the skills to design, develop, implement, and deploy Web based applications.

\section{Acknowledgements}

The authors would like to acknowledge the faculty of the Information Systems \& Computer Programming department who have contributed so much to shape the content of the Internet/Web program.

\section{References}

Maniotes, J., (1973), “The Two Year and Four Year Computer Technology Programs at Purdue University,” Proceedings of the National Computer Conference, June 4-8, pp.371-377.

Mick, M., (1999), “A Two-Track Approach to Integrating Structured and Object-Oriented Programming in an Undergraduate Information Systems Curriculum," Proceedings of ISECON '99, October 14-17, pp.127-133

Raoufi, M. and Maniotes, J, (2000), "Programming I and II Using C++ for Beginning IS Students," Proceedings of ISECON 2000, November 9-12, Paper 105.

Winer, C. and Maniotes, J., (2001), “The Two and Four Year Internet/Web Programs At Purdue University Calumet,” Proceedings of ISECON 2001, November 1-4, Paper 18C

\section{Biographies}

Charles (Chuck) Winer is an Associate Professor and past Acting Department Head in the Information Systems \& Computer Programming Department at Purdue University Calumet. He joined the faculty of the University in 1983. His professional experience includes over thirty years of information systems consulting in the areas of: systems analysis and design, hardware and software evaluation (RFP \& contract considerations), and programming in Microsoft Access and Visual FoxPro, COBOL, Oracle database management system, Information Builders FOCUS/4GL/DBMS, and RPG/400. He holds the Certificate in Data Processing (CDP)/Certified Computing Professional (CCP) designations as awarded by the Institute for Certification of Computer Professionals (ICCP). In addition, he earned the M.A. and B.A. degrees in business education/information systems from Governors State University. Chuck has published several articles in industry journals, presented papers at national and international conferences, been an invited keynote speaker at the $5^{\mathrm{TH}}$ World Multiconference on Systemics, Cybernetics and Informatics (SCI) \& Information Systems Analysis and Synthesis (ISAS) Conference 2000,, been quoted in the PostTribune (Northwest Indiana newspaper), and has been a guest of the local public television station (WYIN) in Northwest Indiana.

Dr. John Maniotes is Professor Emeritus, founder, and first Department Head in the Information Systems \& Computer Programming Department at Purdue University Calumet. He joined the faculty of the University in 1963, where he has been teaching for 38 years. His professional experience includes over 45 years of information systems in the areas of: process control; simulation; computer hardware/software/services selection; and programming in a variety of computer languages. He earned his Ph.D., M.S., and B.S. degrees in Engineering from Purdue University. He has published 13 textbooks, 2 laboratory manuals, over 30 journal articles, and is the holder of one U.S. patent. He has also served as an I.T. consultant to many local school districts; town, city, and county governments; and to business and industry. 


\section{APPENDIX A \\ Purdue University Calumet \\ Information Systems \& Computer Programming Department Bachelors of Science Degree Internet/Web*}

First Semester

$\begin{array}{lcl}\text { CIS } & 166 & \text { Introduction to C++ I } \\ \text { COM } & 114 & \text { Fundamentals of Speech Communications } \\ \text { EET } & 110 & \text { Computer Systems Architecture } \\ \text { ENGL } & 104 & \text { English Composition I } \\ \text { MA } & 153 & \text { Algebra and Trigonometry I }\end{array}$

\section{Second Semester}

$\begin{array}{lll}\text { CIS } & 140 & \text { Introduction to Networks } \\ \text { CIS } & 252 & \text { Systems Analysis and Design } \\ \text { CIS } & 266 & \text { Introduction to C++ II } \\ \text { ENGL } & 105 & \text { English Composition II } \\ \text { MGMT } & 154 & \text { Algebra and Trigonometry II }\end{array}$

\section{Third Semester}

\begin{tabular}{lllr}
\hline CIS & 217 & Object Oriented Programming & 3 \\
CIS & 241 & Web Development I & 3 \\
CIS & 253 & Applied Database Techniques & 3 \\
ECON & 251 & Microeconomics & 3 \\
& & Social Science Elective & $\underline{3}$ \\
\cline { 3 - 3 } & & & 15
\end{tabular}

\section{Fourth Semester}

$\begin{array}{lll}\text { CIS } & 242 & \text { E-Commerce Architecture } \\ \text { CIS } & 263 & \text { JAVA Programming } \\ \text { CIS } & 286 & \text { Operating Systems } \\ & & \text { Humanities Elective } \\ & & \text { General Education Elective }\end{array}$

\section{Fifth Semester}

\begin{tabular}{lrlr}
\hline CIS & 341 & Web Development II & 3 \\
CIS & 342 & Multimedia for Web Designers & 3 \\
CIS & & Elective & 3 \\
ENGL & 302 & Publications Design & 3 \\
MA & 214 & Linear Algebra and Linear Programming & $\underline{3}$ \\
\cline { 3 - 3 } & & & 15
\end{tabular}

\section{Sixth Semester}

\begin{tabular}{lllr} 
CIS & 356 & Topics in Database Programming & 3 \\
CIS & 363 & Advanced JAVA Programming & 3 \\
CIS & 424 & Object-Oriented Analysis and Design & 3 \\
ENGL & 420 & Business Writing & 3 \\
STAT & 301 & Elementary Statistical Methods I & $\underline{3}$ \\
\cline { 3 - 4 } & & &
\end{tabular}

Credits

3

3

3

3

- 3

15

3
3
3
3
3
15

15 
Evolution of a B.S. Internet/Web Program

\section{Seventh Semester}

CIS 442 Internet/Web Security 3

CIS 457 Database Administration 3

ECON 419 Managerial Economics 3

MGMT 324 Marketing Management 3

General Education Elective $\quad \underline{3}$

\section{Eighth Semester}

$\begin{array}{lrlr}\text { CIS } & 426 & \text { System Development Project } & 3 \\ \text { CIS } & 441 & \text { Web Server Management } & 3 \\ \text { CIS } & & \text { Elective } & 3 \\ \text { MGMT } & 354 & \text { Legal Foundations of Business } & 3 \\ & & \text { Natural Science Elective } & 3 \\ & & & 15 \\ & & & \text { TOTAL CREDITS }\end{array}$

For the most current course requirements go to the following URL http://www.cis.calumet.purdue.edu/programs.htm

Also consult the latest edition of the "Graduate and Undergraduate Catalog," Purdue University Calumet, Hammond, Indiana 46323

The High School admission requirements are as follows:

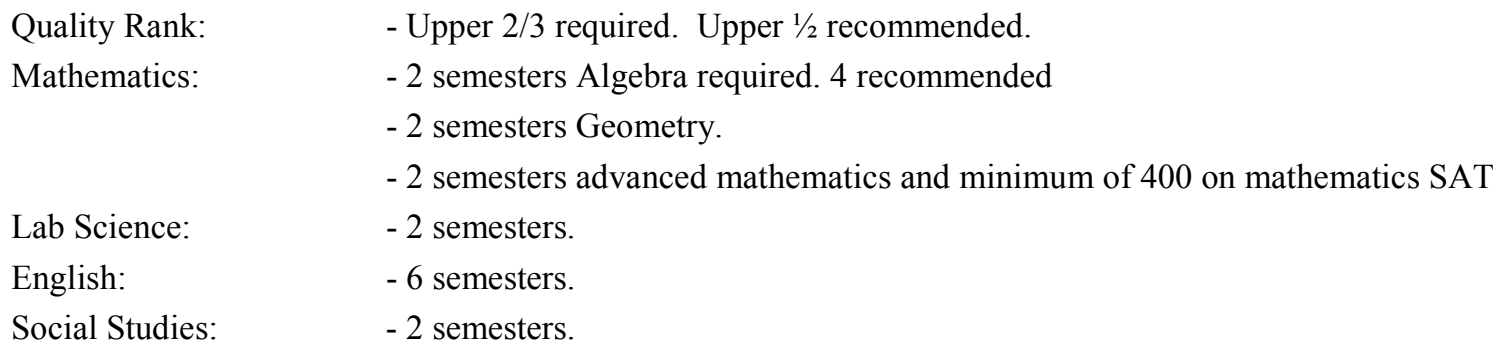

Computer Usage Skills: - An introductory computer course featuring word processing, spread sheets, database concepts, presentation graphics, and Internet usage.

In addition, Humanities and Social Science electives are defined as follows:

Humanities Electives are defined as American History, English Literature, Modern Language, Philosophy, World History, World Literature, or Aesthetics (i.e. Fine Arts, Music, Theater). Social Science Electives are defines as Anthropology, Communications, Economics, Political Science, Psychology, or Sociology. 